\title{
Relict landslides, fluvial landforms and threatened geoheritage - Costești village
}

\author{
Mihai Niculiță, Mihai Ciprian Mărgărint \\ Department of Geography, Faculty of Geography and \\ Geology \\ Alexandru Ioan Cuza University of Iaşi \\ Iaşi, Romania \\ mihai.niculita@uaic.ro,margarint.ciprian@yahoo.com
}

\author{
Ionuţ Cristea \\ Department of Geography \\ Faculty of Geography and History \\ Ştefan cel Mare University of Suceava \\ icristea@atlas.usv.ro
}

\section{INTRODUCTION}

The Moldavian Plateau is a landslide prone region located in North-Eastern and Eastern Romania, the general morphostructural setting of this area consisting of a monocline with cuesta landforms [1]. In the study area, the landslides are characterized by a strong temporal and spatial clustering, being influenced by the morphostructural setting and by the stratified layered rocks. The majority of the hillslopes affected by landslides are characterized by the presence of large old, relict landslides whose morphological signature is degraded by erosion and by younger landslides, the majority of them generating the retreat of the scarps in a retrogressive manner.

The topological relations between several large landslides and archaeological sites for nine selected settlements in the Moldavian Plateau, situated on ridges and hillslopes were studied by [2]. Landslides and archaeological sites were mapped using high resolution LiDAR DEMs and extensive field validation activities were performed for stratigraphic and morphologic recognition, of the landslides, deposits and archaeologic sites relations.

The investigated complex landslides are associated with chalcolithic settlements which are in topologic relations that prove the pre-chalcolitic age of the landslide initiation. While it is clear that post chalcolithic evolution of these landslides involved reactivations and retrogressive patterns, [3] argue that the initial landslide events were triggered in an period when the climatic conditions were completely different than the chalcolithic times, and even, a certain amount of time has passed, since the chalcolithic population used the landslide scarps as defensive measure of protection. The single period that could have the climatic characteristic to generate such big magnitude landslide events is the Upper Pleistocene and its boundary with the Holocene, when the changing climatic conditions could be the trigger for landslides. Giving this context, we state the need of absolute dating, in order to better frame the temporal extension of the landslide activity trough the Upper Pleistocene to Lower Holocene.

\section{CosteșTi Geoheritage Site}

Costeşti - Cier site (Figs 1, 2 and 3) is located in the Bahluieț floodplain on a relict landslide deposit, that comes from failures of both sides of the valley, that possibly blocked the Bahluiet river and nowadays is eroded by Bahluieț river, the morphology being of a terrace remnant. The oldest levels of population of the site is Cucuteni A (6550-5650 y BP). The landslide deposit is covered by a loamy deposit, which is a terrace deposit, overlayed by a paleosoil, and the archaeological remains (Figs 3b and 4). Such a sequence not only is evidence that the landslide is older than the settlement, but older than the Bahluiet, river incision and the loamy floodplain deposition event, which in turn occurred before the formation of a $\sim 30 \mathrm{~cm}$ thick soil. Since the initial failure, the landslide evolved in a retrogressive manner (Fig. 1).

The stratigraphy of the site was interpreted using a 2D ERT scan and the bank stratigraphic section (Figs 3b and 4).

The geoheritage site status was argued by [4] and the actual state of the site represents a typical case of geoheritage sites at risk, in the last 80 years half of the initial site being eroded by the Bahluieț river (according to aerial imagery and local information).

\section{ACKNOWLEDGMENT}

We are grateful to Prut-Bârlad Water Administration who provided us with the LIDAR data. We have used the computational facilities given by the infrastructure provided through the POSCCE-O 2.2.1, SMIS-CSNR 13984-901, No. 257/28.09.2010 Project, CERNESIM (L4).

\section{REFERENCES}

[1] M.C. Mărgărint and M. Niculiţă, "Landslide type and pattern in Moldavian Plateau, NE Romania”, in Landform Dynamics and Evolution in Romania, M. Rădoane and A. Vespremeanu-Stroe, Eds., Springer, 2017, pp. 271-304. doi:10.1007/978-3-319-32589-7_12

[2] M. Niculiță., M.C. Mărgărint, and M. Santangelo, “Archaeological evidence for Holocene landslide activity in the Eastern Carpathian lowland”, Quaternary International, vol. 415, pp. 175-189, 2016.

[3] M. Niculiță., M.C. Mărgărint, and M. Santangelo, "Pleistocene landslides in the Moldavian Plateau, Eastern Romania”, Georeview, vol. 
[4] M. Niculiță. and M.C. Mărgărint, "Landslides and fortified settlements as valuable geoheritage sites in the Moldavian Plateau, NorthEastern Romania, Geoheritage (submitted).

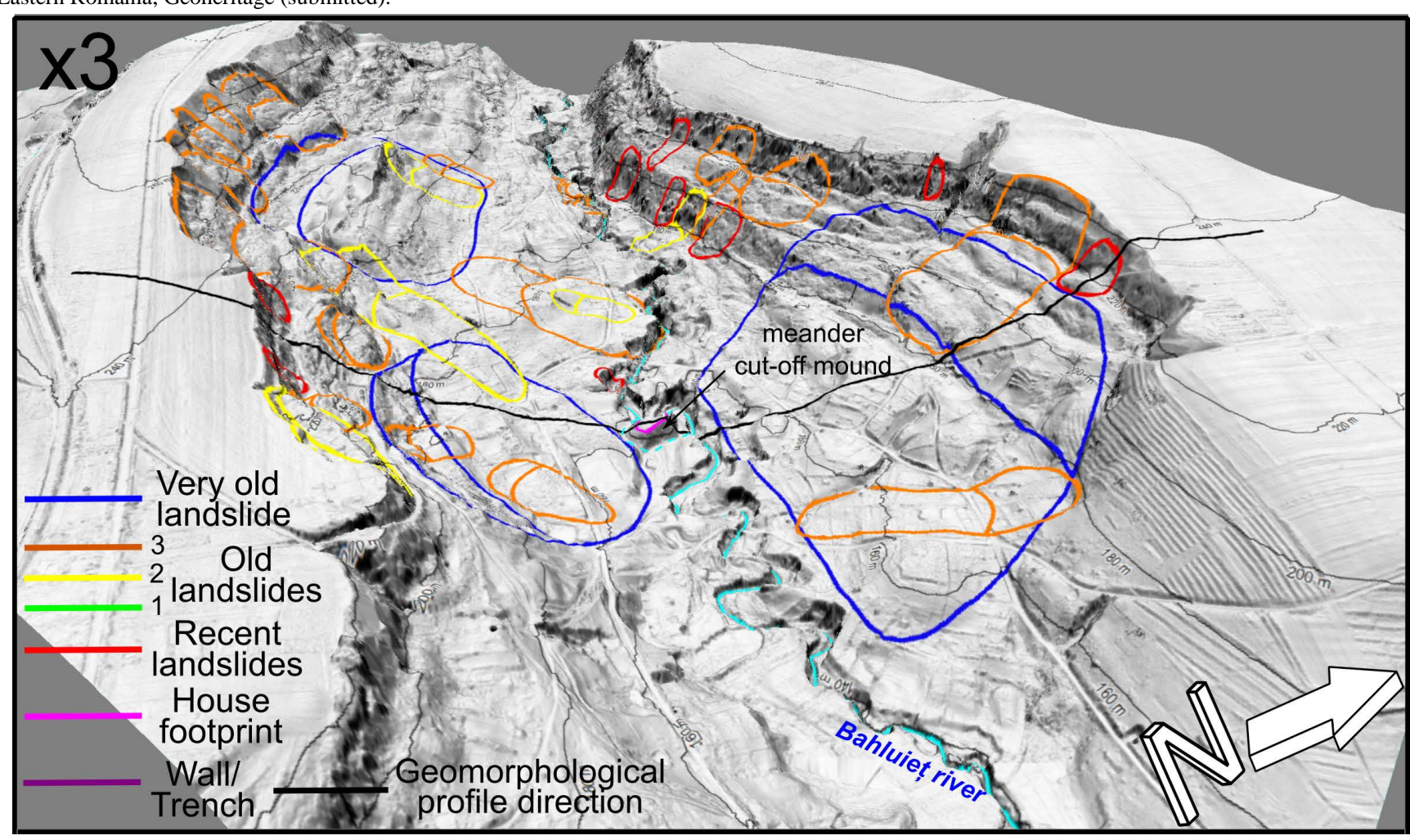

Fig. 1. 3D view of the Costeşti geoheritage site [3]: LiDAR shaded image and the landslide inventory from [1].

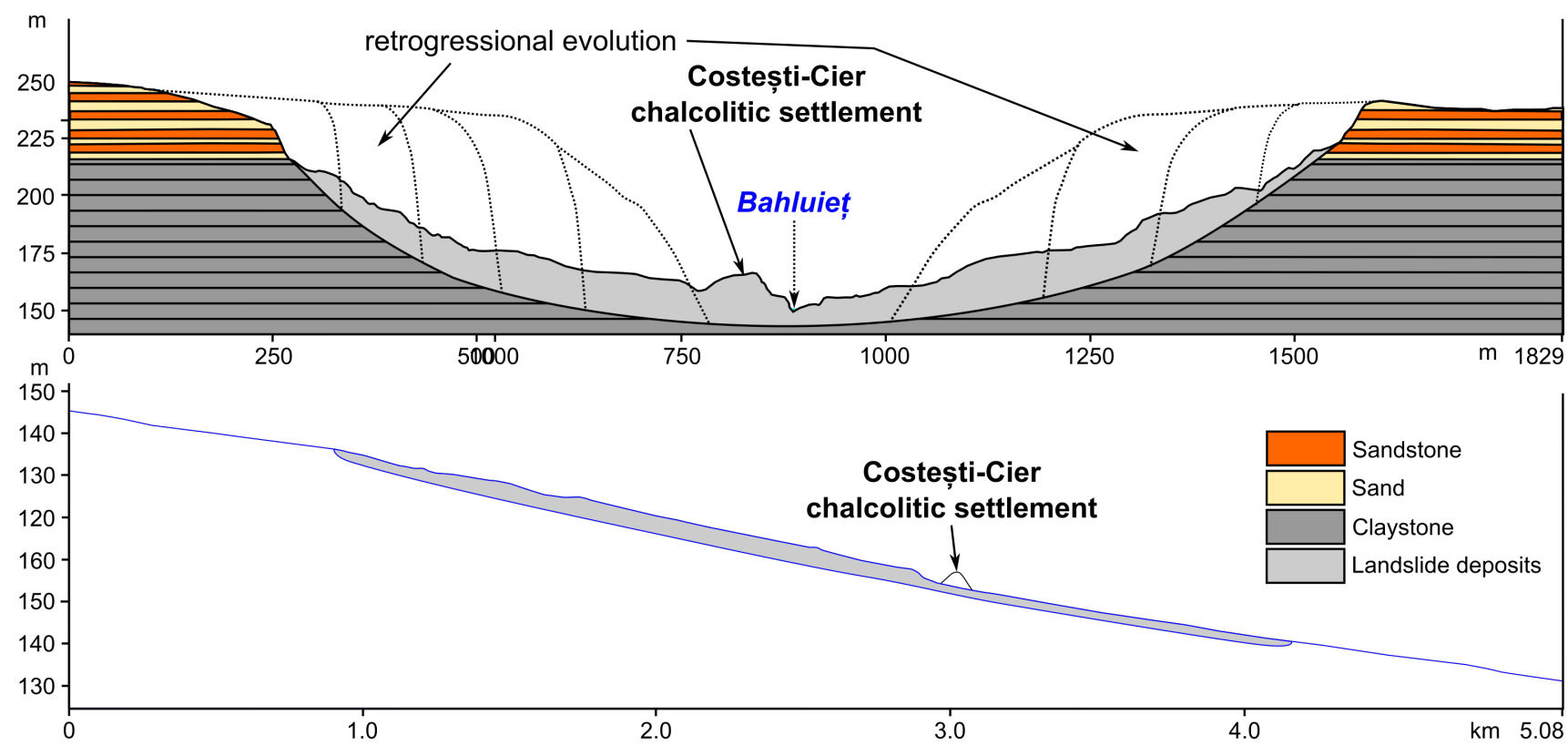

Fig. 2. Geomorphological interpretation of the Costeşti geoheritage site retrogressive mass movement model [2]. 


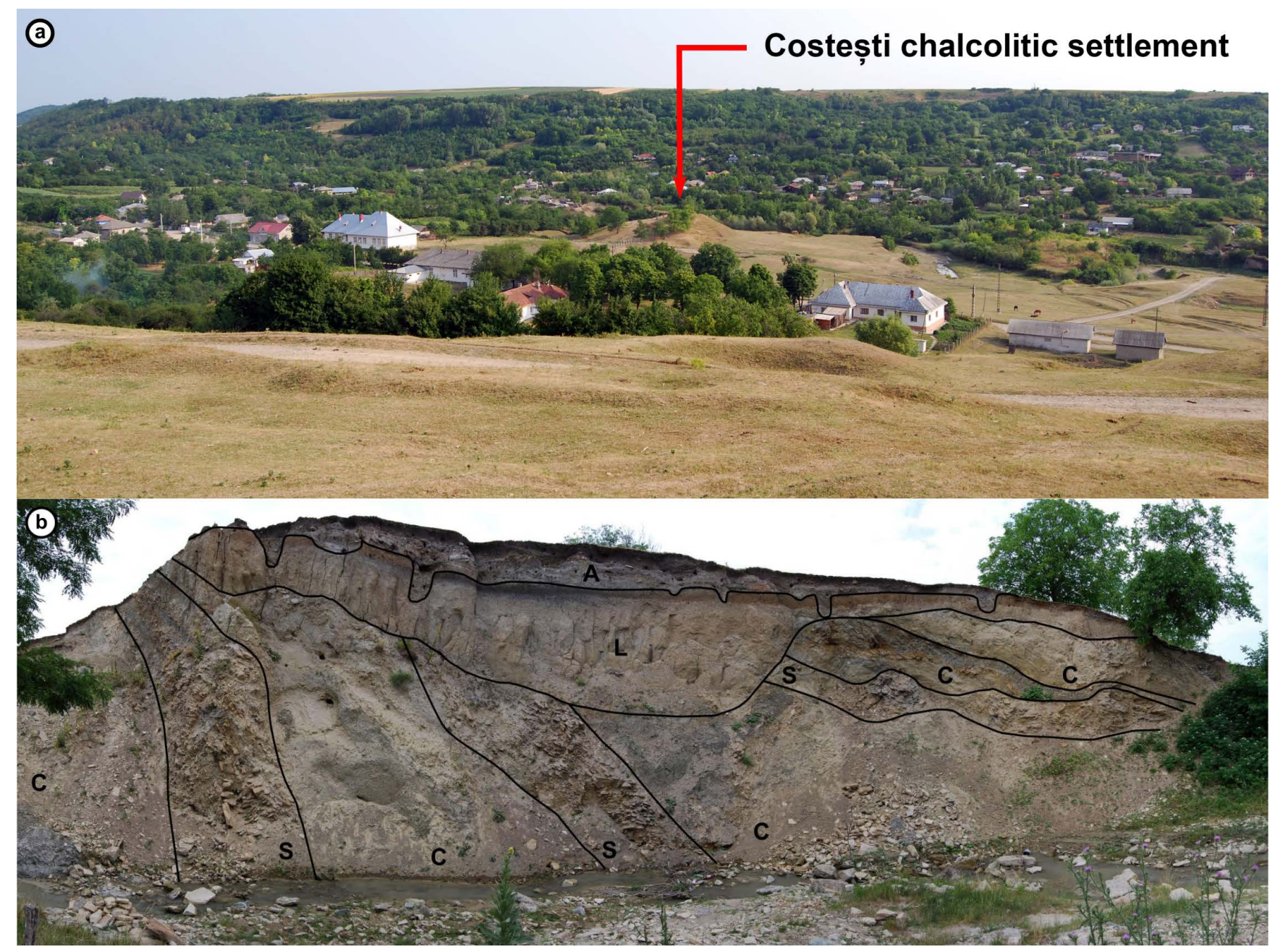

Fig. 3. Costeşti geoheritage site perspective view (a) and stratigraphic section along Bahluieţ bank [1]: A - archaeological deposit, L - loamy terrace deposit, S - sandstone layer, C - clay layer.

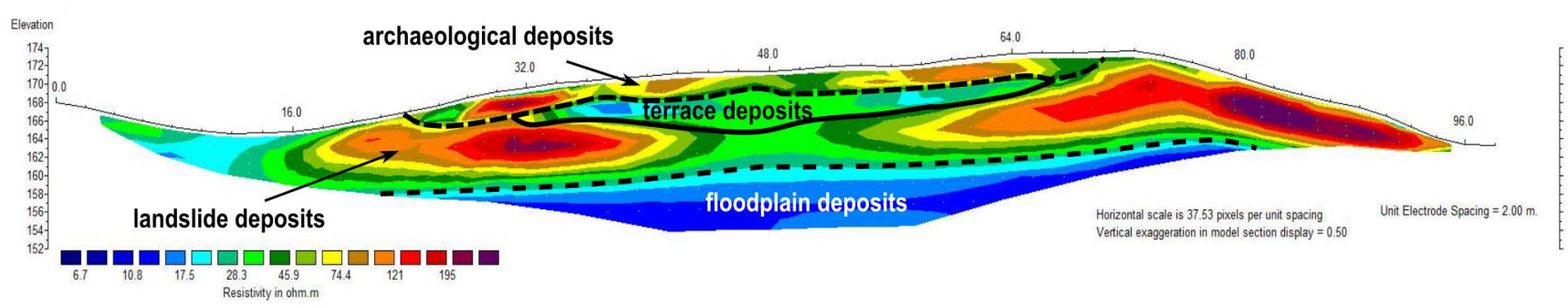

Fig. 4. Costeşti geoheritage site stratigraphy interpreted from 2D ERT. 